\title{
Księgi grodzkie chełmskie jako źródło do badań nad funkcjonowaniem formacji zbrojnych samorządu szlacheckiego
}

ZARYS TREŚCI: W artykule zaprezentowano źródła, na podstawie których możliwe jest opracowanie zagadnienia samorządowych formacji zbrojnych w okresie przedrozbiorowym. Do jego należytego zbadania niezbędne jest wykorzystanie bogatych w informacje ksiąg grodzkich chełmskich z serii Relacje. Poprzez ich analizę Autor omawia treść dokumentów najbardziej pomocnych w odtworzeniu całej procedury związanej $\mathrm{z}$ tworzeniem wojska samorządowego.

sŁowa KLuCzowE: uchwała, pospolite ruszenie, samorząd, księgi grodzkie, sejmik

aвstract: The article presented the sources on the basis of which it was possible to study the issues of local government armed formations in the pre-partition period. To do investigate it properly it is necessary to use the vast store of information included in the Chełm municipal books from the Relation series. Through their analysis the author discusses the content of the documents most helpful in reconstructing the whole procedure connected with the formation of the armed forces raised by local government.

KEYWORDs: resolution, levy in mass, local government, town records, sejmik

Sejmik szlachecki, będąc dobrowolnym zgromadzeniem członków stanu szlacheckiego, pełnił podwójną rolę: z jednej strony był główną instytucją lokalnego samorządu, a z drugiej - podstawą udziału szlachty w życiu politycznym całego państwa. Zgromadzenia szlacheckie regulowały wiele spraw, poczynając 
od politycznych, np. wybór posłów na sejm walny, po administracyjne, np. wybór deputatów do Trybunału Koronnego, trybunałów skarbowych, urzędników grodzkich i ziemskich oraz różnorodnych komisji, których celem było rozwiązywanie licznych praw lokalnej społeczności. Na sesjach sejmików decydowano również o sprawach skarbowych, religijnych i społecznych ${ }^{1}$.

Istotne kompetencje sejmik posiadał również w zakresie organizowania własnych sił zbrojnych. Trzeba nadmienić, że w przypadku pospolitego ruszenia istniały one już od czasów jagiellońskich. To właśnie na samorząd szlachecki spadała zdecydowana większość obowiązków, jeśli chodzi o organizację pospolitaków, i to zarówno na szczeblu lokalnym jak i ogólnopaństwowym² ${ }^{2}$.

Zmiany, jakie dokonały się na przestrzeni lat w kompetencjach sejmików ziemskich, umożliwiały szlachcie powoływanie również innych sił zbrojnych, których zadaniem, z jednej strony, była obrona lokalnego terytorium, a z drugiej wsparcie armii państwowej. Mowa tu o dwóch formacjach: wojsku powiatowym i wyprawach pomiarowych, których działalność regulowały odpowiednie dokumenty urzędowe wytwarzane przez sejmik bądź konkretne osoby ${ }^{3}$. Powstawanie takiego dokumentu związane było z szeregiem czynności, które następowały po oficjalnym zakończeniu obrad przez marszałka sejmiku. Wówczas to dokonywano spisania laudów, instrukcji sejmikowych, a także innych dokumentów, które powstawały jako pochodna postanowień podjętych na sejmiku. Po ich zredagowaniu wybrana przez zgromadzenie szlacheckie grupa osób składała pod nimi swoje podpisy i uwierzytelniała je pieczęciami. W przypadku uchwał i instrukcji sejmikowych podpis swój musiał dodatkowo złożyć marszałek. Aby takie pismo miało moc prawną, przystępowano do ostatniego etapu procedury, czyli wpisania go (oblatowania) w Księdze grodzkiej i opublikowania. Wówczas nabierało ono cech prawomocności i zabezpieczało przed próbami podważenia ${ }^{4}$.

Dokumentacja, która regulowała proces organizacyjny formacji zbrojnych samorządu szlacheckiego i dzięki której możliwe jest jego odtworzenie, znajduje

${ }^{1}$ W. Kriegseisen, Sejmiki Rzeczypospolitej Szlacheckiej w XVII i XVIII w., Warszawa 1991, s. $15-16$.

2 D. Kupisz, Wojska powiatowe samorzadów Małopolski i Rusi Czerwonej w latach 1572-1717, Lublin 2008, s. 23; A. Wyczański, Z dziejów reform skarbowo-wojskowych za Zygmunta I. Próba relucji pospolitego ruszenia, „Przegląd Historyczny” (dalej: PH), t. 43, 1952, z. 2, s. 301-303.

3 J. Wimmer, Wojsko polskie w drugiej połowie XVII wieku, wyd. 2, Oświęcim 2013, s. 27; idem, Wojskowość polska w latach 1648-1699, [w:] Zarys dziejów wojskowości polskiej do roku 1864, t. 2 (1648-1864), red. J. Sikorski, Warszawa 1966, s. 24-25, 26-28.

${ }^{4}$ W. Kriegseisen, op. cit., s. 62. 
się w Księgach grodzkich z serii Relacje, zarówno w formie czystopiśmiennej (inducta) jak i brudnopisach (protocollon). Chcąc możliwie jak najszerzej omówić zagadnienie podstawy źródłowej niezbędnej do opisania procesu organizowania, formowania i działania samorządowych sił zbrojnych, warto rozpocząć od krótkiego zaprezentowania specyfiki omawianych formacji oraz stanu badań nad nimi w kontekście ziemi chełmskiej.

Konieczne wydaje się również wyjaśnienie samej koncepcji artykułu. Jego celem nie jest omawianie poszczególnych formacji zbrojnych samorządu szlacheckiego, poniższy bardzo skrócony opis ma jedynie za zadanie przybliżyć czytelnikowi samo zagadnienie. W tekście zostało przedstawionych kilka przykładów powoływania różnych formacji, ale mają one na celu jedynie wskazanie źródeł, które pozwoliły na odtworzenie procesu organizacyjnego i działalności poszczególnych formacji oraz ich analiza w zakresie przydatności dla badacza. Celem artykułu nie jest zatem dokładne opisywanie procesu formowania i działalności wojskowej poszczególnych jednostek, ponieważ takie ustalenia znajdują się już w dotychczas wydanej literaturze.

\section{Formacje zbrojne samorządu szlacheckiego i stan badań nad nimi}

W zakresie formowania własnej siły zbrojnej sejmik szlachecki, jak już wcześniej wspomniano, miał wpływ na organizację i tworzenie trzech formacji: wojska powiatowego, pospolitego ruszenia oraz wypraw pomiarowych. Wojsko powiatowe było formacją opartą na zasadach zaciągu regularnego; jej funkcjonowanie warunkowały konstytucje z lat 1613-1619. Wówczas samorządy dostały możliwość tworzenia własnych zaciągów, w momentach gdy zaistniała taka potrzeba. Tego typu kompetencje przekazane do sejmiku mocno wkraczały w uprawnienia króla, co początkowo nie tylko nie zyskało jego aprobaty, a wręcz wywołało wrogość. $\mathrm{Z}$ czasem jednak wypracowano pewien kompromis organizacyjny. Polegał on na tym, że wszystkie najważniejsze elementy związane z zaciągiem regulował sejmik, co zostanie wykazane przy okazji konkretnych typów dokumentacji, rolą króla było jedynie zatwierdzenie uchwalonych wojsk i dowodzących nimi oficerów ${ }^{6}$.

5 Volumina Constitutionum, t. 3 (1611-1640), vol. 1 (1611-1626), red. S. Grodziski, M. Kwiecień, A. Karbowicz, Warszawa 2010, s. 118, 177, 246.

${ }^{6}$ D. Kupisz, Wojska powiatowe, s. 131-134. 
Druga formacja, czyli pospolite ruszenie, przez wiele lat uważana była za formację ogólnopaństwową, a nie samorządową. Patrząc jednak na liczbę czynności, które wykonywały samorządy przy jej organizacji, sposób rozstrzygnięcia tego problemu wydaje się oczywisty. Główną cechą charakterystyczną pospolitego ruszenia był wysiłek mobilizacyjny wszystkich posiadaczy ziemskich w państwie ${ }^{7}$. Niestety powszechność uczestnictwa w takich wyprawach bardzo często odbijała się na ich jakości, szukano więc rozwiązań kompromisowych i bardziej skutecznych.

Wyprawy pomiarowe miały stanowić substytut dla niewydolnego pospolitego ruszenia. Ich istotą było zobligowanie posiadaczy ziemskich, by z określonej miary ziemi bądź dymów wystawiali jednego pieszego bądź konnego z pełnym uzbrojeniem oraz gwarantowali jego utrzymanie. Początkowo przelicznik zależał od ilości łanów, a następnie od 1673 r. od ilości dymów ${ }^{8}$.Wszystkie te trzy formacje zamiennie bądź naraz powoływał sejmik w razie konieczności.

Analiza ich funkcjonowania na obszarze podległym sejmikowi ziemi chełmskiej pojawiła się w kilku monografiach. Po pierwsze należy wskazać opracowania książkowe Roberta Kozyrskiego ${ }^{9}$ i Jerzego Ternesa ${ }^{10}$, które oprócz wielu istotnych zagadnień związanych z działalnością sejmiku w ogóle, poświęcały uwagę także samorządowym formacjom zbrojnym. Praca autorstwa Antoniego Prochaski, dotycząca samorządu ziemi chełmskiej, opublikowana na łamach „Przeglądu Historycznego", również podnosiła takie wątki ${ }^{11}$. Formacje samorządowe ziemi chełmskiej pojawiały się też w opracowaniach poświęconych konkretnym formacjom zbrojnym. Można tu wskazać m.in. opracowania Dariusza

${ }^{7}$ K. Hahn, Pospolite ruszenie wedle uchwat sejmikowych ruskich od XVI do XVIII wieku, „Pamiętnik Historyczno-Prawny”, t. 6, 1928, cz. 4, s. 4-16, 43-46.

${ }^{8}$ D. Kupisz, Wyprawy żołnierza łanowego w Koronie w czasach Jana Kazimierza, Warszawa 2018, s. 271-274; T. Ciesielski, Wyprawa łanowa 1653 r., „Zeszyty Naukowe Wyższej Szkoły Pedagogicznej im. Powstańców Śląskich w Opolu. Historia”, t. 30, 1994, s. 47-49.

${ }_{9}$ R. Kozyrski, Sejmik szlachecki ziemi chetmskiej 1648-1717, Lublin 2006.

10 J. Ternes, Sejmik chełmski za Wazów (1587-1668), Lublin 2004.

11 A. Prochaska, Z dziejów samorządu ziemi chetmskiej, PH, t. 6, 1908, cz. 1-3, s. 33-49, 155-172, 306-321. 
Kupisza $^{12}$, Leszka Wierzbickiego ${ }^{13}$, Mirosława Nagielskiego ${ }^{14}$, Zbigniewa Hun$\operatorname{derta}^{15}$, Alberta Borowiaka ${ }^{16}$ i Tomasza Ciesielskiego ${ }^{17}$. Formacjom zbrojnym ziemi chełmskiej poświęcone były oddzielne artykuły autorstwa D. Kupisza ${ }^{18}$ i L. Wierzbickiego ${ }^{19}$. Natomiast temat dokumentacji będącej wytworem sejmiku i związanej z działalnością samorządu szlacheckiego, w tym z zagadnieniem jego formacji zbrojnych, pojawił się w pracach Janusza Łosowskiego ${ }^{20}$ oraz w edycjach źródłowych R. Kozyrskiego ${ }^{21}$ i Henryka Gmiterkaa ${ }^{22}$. Materiał z ksiąg grodzkich pozwolił również autorowi niniejszego artykułu na zaprezentowanie wojskowej działalności samorządowej dwóch postaci - Jana Karola Romanowskiego oraz Samuela Regowskiego ${ }^{23}$. Warto też dodać, że akta sejmikowe z okresu panowania

12 D. Kupisz, Wyprawy żolnierza łanowego; idem, Wojska powiatowe samorządów Małopolski $i$ Rusi Czerwonej w latach 1572-1717, Lublin 2008, s. 23.

${ }^{13}$ L. Wierzbicki, Pospolite ruszenie w Polsce $w$ drugiej połowie XVII wieku. Ostatnie wyprawy $z$ lat 1670-1672, Lublin 2011; idem, Wici na pospolite ruszenie $w$ Koronie w latach 1669-1673, „Res Historica”, t. 26, 2008, s. 43-48; idem, Uczestnicy wypraw pospolitego ruszenia koronnego w czasach panowania Michała Korybuta Wiśniowieckiego, [w:] Społeczeństwo staropolskie, t. 4, Społeczeństwo a wojsko, red. I. Dacka-Górzyńska, A. Karpiński, M. Nagielski, Warszawa 2015, s. 155-166.

${ }_{14}$ M. Nagielski, Pospolite ruszenie szlachty w świetle kampanii zborowskiej i beresteckiej przeciwko Kozakom (1649-1651), [w:] Armia i społeczeństwo, „Studia Historyczno-Wojskowe”, t. 3, red. T. Ciesielski, Zabrze 2009, s. 94-112.

${ }^{15}$ Z. Hundert, Między buława a tronem. Wojsko koronne w walce stronnictwa malkontentów $z$ ugrupowaniem dworskim w latach 1669-1673, Oświęcim 2019.

16 A. Borowiak, Wojska powiatowe przed kampaniq piławiecka w 1648 r., [w:] Staropolska sztuka wojenna, t. 2, red. Z. Hundert, Oświęcim 2013, s. 129-161.

17 T. Ciesielski, Wyprawa łanowa 1653 r., s. 47-80.

${ }_{18}$ D. Kupisz, Choragwie powiatowe ziemi chełmskiej w XVI-XVII wieku, „Rocznik Chełmski” (dalej: RC), t. 10, 2006, s. 57-71.

19 L. Wierzbicki, Szlachta chetmska w czasie konfederacji gołębskiej, RC, t. 6, 2000, s. 55-70.

${ }^{20} \mathrm{~J}$. Łosowski, Kancelaria grodzka chetmska od XV do XVIII wieku. Studium o urzędzie, dokumentacji, jej formach $i$ roli $w$ życiu społeczeństwa staropolskiego, Lublin 2004; idem, Akta sądów i urzędów szlacheckich w XIV-XVIII wieku, [w:] Dyplomatyka staropolska, red. T. Jurek, Warszawa 2015, s. 253-336; idem, Uniwersały królewskie i ich rola w procesie przygotowania działań wojennych na szczeblu powiatu w XVII w., „Studia Archiwalne”, t. 2, 2006, s. 73-94.

${ }^{21}$ R. Kozyrski, Popisy (okazowania) szlachty w Rzeczypospolitej w II połowie XVII w. Popis Chetmian $z 7$ sierpnia 1649 r., RC, t. 7, 2001, s. 341-358.

${ }^{22}$ H. Gmiterek, Rejestry szlachty ziemi chetmskiej z lat 1669-1672, RC, t. 2, 1996, s. 327-339.

${ }^{23}$ B. Staręgowski, Działalność wojskowa i polityczna Jana Karola Romanowskiego - rotmistrza i podkomorzego ziemi chetmskiej, RC, t. 20, 2016, s. 45-59; idem, Oficer wojsk formacji zbrojnych samorzadu ziemskiego - na przykładzie Samuela z Pękosławia Regowskiego, podczaszego chełmskiego, RC, t. 21, 2017, s. 25-45. 
dynastii Wazów zostały wydane w formie książkowej - edycja źródłowa - autorstwa Wiesława Bondyry, H. Gmiterka i J. Ternesa ${ }^{24}$.

\section{Dokumenty będące bezpośrednim wytworem sejmików ziemskich}

Aby odpowiednio zarysować obszar terytorialny sejmiku, którego dokumenty stanowią podstawę analizy, należy wspomnieć, że dotyczy on jednostki administracyjnej, jaką była ziemia chełmska, poszerzona dodatkowo o obszar powiatu krasnostawskiego - jego przedstawiciele szlacheccy uczestniczyli we wspólnych zjazdach ze szlachtą chełmską. Sama ziemia wchodziła w skład województwa ruskiego, ale w jego ramach cieszyła się sporą autonomią. Mimo iż nie posiadała własnego wojewody, jej status porównywalny był do udzielnego województwa z uwagi na niezależność własnego sejmiku oraz co najistotniejsze możliwość wysyłania posłów bezpośrednio na sejm bez konieczności brania udziału w sejmikach generalnych ruskich (z wyjątkiem bezkrólewia i konfederacji).

Obrady odbywały się z reguły w kościele farnym w Chełmie pw. Rozesłania Świętych Apostołów, ale zdarzały się przypadki obrad w Krasnymstawie, Łopiennikach czy Wojsławicach. Świątynia stwarzała odpowiednie możliwości do odbycia sesji, jednakże szlachta przybywająca z okolic często żaliła się na brak kwater pozwalających na nocleg. $W$ wyjątkowych przypadkach, np. $z$ uwagi na dużą liczbę zgromadzonych przenoszono obrady poza Chełm ${ }^{25}$.

Przechodząc do meritum, należy nadmienić, że najważniejszymi dokumentami umożliwiającymi funkcjonowanie formacji zbrojnych samorządu były uchwały (lauda) sejmikowe. To one regulowały kwestie związane z rodzajem formacji, sposobami zapłaty, określały miejsce i czas popisów oraz ustalały liczbę łanów czy dymów, z których należało wystawiać żołnierzy, a także powoływały dowódców i wyznaczały oddziałom miejsca stacjonowania ${ }^{26}$. Posłużmy się przykładem.

Na sejmie 9 IX 1670 r. uchwalono konstytucję, która nakazywała zaciąganie wojska powiatowego i jego mobilizację do maja przyszłego roku. Regulowała

\footnotetext{
${ }^{24}$ Akta sejmikowe Ziemi Chetmskiej 1572-1668 (dalej: ASZCh), oprac. W. Bondyra, H. Gmiterek, J. Ternes, Lublin 2013.

${ }^{25}$ J. Ternes, op. cit., s. 23-26, 29-30; R. Kozyrski, Sejmik szlachecki, s. 37-41; H. Gmiterek, W czasach Rzeczypospolitej szlacheckiej, [w:] Chetm i chetmskie w dziejach, red. R. Szczygieł, Chełm 1996, s. 57; A. Prochaska, op. cit., s. 35-36.

${ }^{26}$ D. Kupisz, Wojska powiatowe, s. 132, 381; idem, Choragwie powiatowe, s. 57-58.
} 
również inne kwestie związane z zaciągiem żołnierza powiatowego ${ }^{27}$. W związku z perturbacjami politycznymi dopiero sejmik ziemi chełmskiej z 28 IX $1671 \mathrm{r}$. podjął decyzję o organizacji wojska powiatowego w liczbie 140 koni, podzielonego na dwie chorągwie jazdy, liczące po 70 pancernych, których oddano pod komendę Stanisławowi Stawskiemu i Eliaszowi Żółkiewskiemu „jako ludzi zasłużonych i wojnie dawno traktujących (...)”. Laudum zawiera także informację, że żołd miał być wydany w wysokości 2000 złp dla chorągwi i 1000 złp nagrody dla rotmistrzów. Na miejsce wybierania stacji wskazano dla każdego z rotmistrzów inne miejscowości: dla Stawskiego Opalin i Ratno, a dla Żółkiewskiego - Żmudź, Roztokę i Depułtycze. Określanie miejsc wyboru stacji żołnierskich oraz ich wielkości zabezpieczało przed nadużyciami ze strony chorągwi. Dalej uchwała wskazywała na konieczność stawienia się przed wymienionymi komisarzami po skompletowaniu oddziału, by wybrani dygnitarze mogli sprawdzić kompletność chorągwi oraz wyeliminować ewentualne oszustwa przy pobieraniu żołdu. W uchwale znajdowała się również pełna procedura poboru podatków z wyznaczeniem wielkości poboru, poborców, szafarzy oraz czasu potrzebnego do jego wybrania. W drugiej połowie XVII w. istniał problem szybkiego i skutecznego wybierania podatków. Aby usprawnić ten proces, sejmiki mogły zalecić egzekucje wojskowe, przy udziale powołanych chorągwi. Sejmik z września wyrażał swoją aprobatę dla takich działań ${ }^{28}$. Egzekucje skarbowe były oddzielnie dokumentowane, a następnie wpisywane do ksiąg grodów, co pozwala dowiedzieć się, czy chorągwie dokonywały takich czynów czy nie.

Procedura powoływania chorągwi obrony domowej wyglądała podobnie, pojawiały się tylko bardziej szczegółowe zapisy odnośnie do ochrony przez nie najbliższego terytorium, a w niektórych przypadkach nawet wyznaczenie obszarów patrolowych, które miały być ochraniane. Na marginesie wypada wspomnieć, że ziemia chełmska była prekursorem w powoływaniu żołnierza powiatowego w charakterze samoobrony terytorialnej, gdyż dokonała tego już w 1572 r., choć konstytucje regulujące tego typu wojska pojawiły się dopiero na początku XVII w. ${ }^{29}$ Niebezpieczeństwo związane z powstaniem Bohdana Chmielnickiego na Ukrainie oraz klęska wojska koronnego pod Batohem wywołały lęk na obszarach, które mogły paść ofiarą najazdu armii zaporoskiej. Sejmik chełmski podjął wobec

27 Volumina Legum, t. 5, Od roku 1732 do roku 1782, Petersburg 1860 (dalej: VLV), s. 30-31.

28 Archiwum Państwowe w Lublinie (dalej: APL), Księgi grodzkie chełmskie (dalej: Kgch), Relacje, sygn. 90, s. 1395-1400, Laudum chełmskie, Chełm 28 IX $1671 \mathrm{r}$.

29 D. Kupisz, Choragwie powiatowe, s. 58-59. 
tego działania zmierzające do ochrony swoich obywateli ${ }^{30}$. Zacytujmy zatem ustęp uchwały chełmskiej z 11 VI 1652 r.:

Naprzód, iż podczas sejmiku teraźniejszego perculit et preservit nas wiadomość ex callida perfidia hostis clades praecipui roboris wojska Rzeczypospolitej (...) za którym fatalnym, niespodziewanym i prędkim przypadkiem prędkością nieprzyjaciela (...) perterriti (...) sama tylko prawie ziemia nasza chełmska, jako już temu niebezpieczeństwu pierwsza i pograniczna, aby jako cokolwiek mogła salvare metum et confusionem populationis i dla pohamowania seditionum ausus poddanych swoich, ludzi służałych koni sto po kozacku uchwalamy (...).

Z uwagi na to, że obszar ziemi chełmskiej nie był szczególnie rozległy, najczęściej wystarczyła tylko jedna chorągiew, pod komendą rotmistrza, aby zapewnić bezpieczeństwo całego terytorium ${ }^{31}$.

Nieco inaczej sprawa wyglądała w przypadku wypraw pospolitego ruszenia. Czasem w uchwałach znajdowała się tylko krótka wzmianka o organizacji, ale momentami można było znaleźć bardziej rozbudowane wytyczne. We wszystkich jednak znajduje się odniesienie do wydania przez króla trzecich wici:

My rady, dygnitarze, urzędnicy i wszystko rycerstwo ziemi chełmskiej i powiatu krasnostawskiego zjechawszy się do Chełma na miejsce constitutionum zwyczajne z uniwersału wici trzecich od króla JMPana (...) wydanych (...).

To świadczyło, że zwołanie pospolitego ruszenia odbywa się w zgodzie z prawem. Następnie zależnie od okoliczności laudum zawierało więcej lub mniej regulacji. Jego treść w znacznej mierze powielała również zapisy konstytucji sejmowej. W tej z września $1670 \mathrm{r}$. zawarte zostały jedynie wzmianki o tym, że wyprawa ma się odbywać według „dawnych praw”32, natomiast uchwała sejmiku z 2 X 1670 r. nie tylko wskazywała miejsce i czas popisu, czyli $12 \mathrm{X}$ pod Kransystawem, ale

\footnotetext{
${ }^{30}$ Ibidem, s. 63-64.

${ }^{31}$ Kgch, Relacje, sygn. 74, s. 261-266, Laudum chełmskie, Chełm 11 VI 1652; ASZCh, s. 322-325, Laudum sejmiku przedsejmowego 11 czerwca 1652 r.

${ }^{32} V L$ V, s. 28-29.
} 
również wyznaczała duktora w osobie Marcina Orchowskiego, na co dowodem jest następujący zapis:

\section{(...) uprosiliśmy tedy (...) JMPana Marcina z Orchowca Orchowskiego} podstolego ziemi naszej za generalnego porucznika i zaraz (...) tysiąc złotych z czopowego teraźniejszego dać pozwalamy (...).

Według tego fragmentu Orchowski poprowadzić miał szlachtę i otrzymać za to pewną sumę pieniędzy. W dalszej część uchwały znajduje się też nakaz wydania pewnych kwot na pokrycie kosztów obozowania. Istotne było również powołanie sędziów, mających karać wszelkie przejawy niesubordynacji szlacheckiej i czuwających nad właściwym przebiegiem organizacji wyprawy. Laudum przewidywało zmianę prawodawstwa na czas wyprawy oraz wprowadzało nowe kary i obowiązki dla szlachty, w tym także bezwzględne posłuszeństwo wobec duktora ${ }^{33}$.

W przypadku zaprezentowanego laudum, można zauważyć, że pewnych ustaleń jest dosyć sporo. Najczęściej jednak ograniczano się jedynie do ustalenia miejsca popisu oraz wskazania, że pospolite ruszenie będzie organizowane według założeń konstytucji sejmowych, które regulowały wcześniejsze wyprawy i stanowiły punkt odniesienia i wzór dla aktualnej organizacji. Laudum z 9 V 1651 r., w przypadku wyprawy pospolitego ruszenia pod Berestecko, wskazywało jedynie wybranego duktora, którym został Adam Pszonka, chorąży chełmski ${ }^{34}$.

Formowanie wypraw pomiarowych było znacznie bardziej skomplikowane. Biorąc za przykład uchwałę z 10 VI 1653 r., można wskazać pewne prawidłowości. W pierwszej kolejności powoływano komisarzy, „którym to Imch. Panom komisarzom dajemy authoritatem i moc do grodów, naprzód denuncjacją o uniwersale Króla JMci i ruszaniu się województw albo ich ludzi, a potem komputacyji łanów i kombinacyji wsi i wyprawy, ponieważ się sami ichmciowie na popisie combinare nie mogli (...)". Zadaniem powołanej komisji kombinacyjnej było przeliczenie łanów w danej ziemi i województwie, a następnie nadzorowanie procesu wystawiania żołnierzy proporcjonalnie do ich ilości. Szlachta chełmska w 1653 r. powołała czterech komisarzy, po dwóch do ziemi chełmskiej i powiatu krasnostawskiego. Ponadto uchwała decydowała o liczbie łanów, z których wystawiani mieli być żołnierze, określała, jaki rodzaj dóbr będzie obciążony koniecznością ich wystawienia, a także rodzaj wyprawy - czy będzie ona piesza czy konna, powoływała

\footnotetext{
${ }^{33}$ Kgch, Relacje, sygn. 89, s. 601-603, Laudum chełmskie, Chełm 2 X 1670.

${ }^{34}$ ASZCh, s. 307, Laudum sejmiku przed pospolitym ruszeniem 9 maja 1651 r.
} 
rotmistrzów i wyznaczała im powiaty, gdzie odbierać mieli żołnierzy. Uregulowano również sprawę zapłaty żołdu. Rotmistrzem wyprawy w 1653 r. został Jan Karol Romanowski, któremu naznaczono 2000 złp do odebrania u Marcina Borzęckiego, wojskiego bełskiego. Sejmik przewidywał nawet powołanie drugiego rotmistrza, ale odłożył tę decyzję na później ${ }^{35}$.

Lauda sejmikowe stanowią najważniejsze źródło do badań nad formacjami samorządu szlacheckiego i bez ich gruntownej analizy niemożliwe jest właściwe opracowanie tego zagadnienia. Stanowią bezwzględną podstawę źródłową, jednakże zawarte w nich informacje pozwalają badaczowi określić jedynie wstępny moment tworzenia formacji zbrojnych. W wielu przypadkach ich treść doskonale koresponduje z konstytucjami sejmowymi, a konkretne wytyczne powielane są w uchwałach sejmikowych. Niestety nie pozwalają nam poznać dalszych losów zaciągów, a w szczególności odpowiedzieć na pytanie, czy dany zaciąg doszedł do skutku czy też nie. W wyjątkowo rzadkich przypadkach następujących po sobie laud, możemy dowiedzieć się, czy zrealizowano zamierzenia poprzedniego zgromadzenia. Nie jest to jednak reguła, a nawet jeśli takowe wzmianki pojawiają się, są jedynie lakoniczne. Bardziej szczegółowych informacji co do następstw uchwał sejmikowych należy szukać w innych dokumentach.

Oprócz uchwał, bezpośrednim wytworem prac sejmików przedsejmowych były instrukcje poselskie na sejm walny. Nie stanowią one takiego źródła wiedzy jak lauda, aczkolwiek możemy w nich odkryć inne ciekawe informacje. W takich dokumentach często możemy poznać wytyczne sejmikowe dla posłów odnośnie do umocowań prawnych dla danej formacji zbrojnej samorządu, np. zatroszczenie się o wydanie listów przypowiednich dla rotmistrzów czy pułkowników, objęcie określonych dóbr obowiązkiem kombinacji łanowej czy też koekwacji łanów w innych ziemiach i województwach ${ }^{36}$. Jednym $\mathrm{z}$ istotniejszych poleceń dla posłów było staranie się o zaaprobowanie przez sejm uchwalonych sposobów obrony $^{37}$, na co dowód znajdujemy w treści instrukcji z 1672 r., w której szlachta chełmska domagała się uznania uchwalonej przez nią wyprawy łanowej według konstytucji z 1655 r., pozostawiając sobie również możliwość zwołania pospolitego ruszenia $^{38}$. Instrukcje zawierały również wnioski o wypłatę nagród dla szczególnie

${ }^{35}$ Kgch, Relacje, sygn. 74, s. 685-689, Laudum chełmskie, Obóz pod Chełmem 10 VI 1653 r.; ASZCh, s. 344-346, Laudum w czasie popisu 10 czerwca 1653 r.

${ }^{36}$ Ibidem, s. 1914-1915, Instrukcja sejmikowa, Chełm 28 IV 1655 r.; ASZCh, s. 386-387, Instrukcja posłom na sejm $z$ sejmiku przedsejmowego 28 kwietnia 1655 r.

${ }^{37}$ ASZCh, s. 288, Instrukcja posłom na sejm z sejmiku przedsejmowego 11 października 1649 r.

${ }^{38}$ Kgch, Relacje, Akta luźne, sygn. 3, k. 142v, Instrukcja sejmikowa, Chełm 22 I 1670 r. 
zasłużonych żołnierzy i oficerów ${ }^{39}$, czego przykładem jest instrukcja sejmiku Z 13 XII 1672 r., która obligowała posłów do starań o nagrodę dla porucznika powiatowego Oktawiana Sosnowskiego, „który przez lat piętnaście pod husarską chorągwią (...) tak w wojsku litewskim jako i koronnym służąc przez lata $\mathrm{w}$ różnych expeditiach i w ciężkiem pod Korsuniem więzieniu zostając straciwszy wszystkie substancje swoje (...) confirmatie (...) przywilejów otrzymał (..." ${ }^{\prime 40}$.

\section{Dokumentacja wytworzona przez władze centralne i lokalne}

Oprócz dokumentacji będącej bezpośrednim wytworem pracy sejmików w księgach grodzkich oblatowano również uniwersały i listy przypowiednie. W tych pierwszych król ustalał miejsce koncentracji i informował o zbliżającej się kampanii wojskowej ${ }^{41}$. W przypadku uniwersału, który stanowił trzecie wici na pospolite ruszenie, dokumenty te pozwalały szlachcie na podejmowanie dalszych kroków w organizacji wyprawy. Uniwersały najczęściej wydawał król, ale także inne osoby w postaci hetmanów, wyższych urzędników czy oficerów ${ }^{42}$. Treść uniwersałów królewskich zazwyczaj była tak sformułowana, by nie tylko podawać najistotniejsze informacje, ale również wywierać pewien określony wpływ. Narracja propagandowa miała na celu zmobilizowanie szlachty do uczestnictwa w działaniach zbrojnych. Dlatego też mówiąc o zagrożeniu, odwoływano się do odwagi szlachty, miłości do ojczyzny oraz przywiązania do religii. Równie często po prostu wyolbrzymiano zagrożenie ${ }^{43}$. Ciekawym przykładem jest uniwersał króla Michała Korybuta Wiśniowieckiego z 25 IV 1670 r. Monarcha relacjonował $\mathrm{w}$ nim ostatnie wydarzenia polityczne, a mianowicie walkę na sejmie z opozycją i zwrócił się do szlachty o to, by była w gotowości stawić się na pospolite ruszenie w przyszłości i zaakceptowała wydanie „jednych wici za dwoje”"44. Sam dokument

\footnotetext{
${ }^{39}$ Ibidem, s. 285, 291.

${ }^{40}$ Kgch, Relacje, sygn. 91, s. 798, Instrukcja sejmikowa, Chełm 13 XII 1672 r.

${ }^{41}$ L. Wierzbicki, Szlachta chetmska, s. 57.

42 J. Łosowski, Uniwersały królewskie, s. 74-76; idem, Kancelaria grodzka, s. 319-320; B. Staręgowski, Praktyczne znaczenie przekazu wojennego w uniwersałach króla Jana Kazimierza 1648-1668, [w:] Przekaz informacji o wojnie i na wojnie. Z dziejów wojskowości polskiej i powszechnej, t. 8, Homo Militans, red. A Niewiński, Lublin 2019, s. 130-135.

${ }^{43}$ B. Staręgowski, Praktyczne znaczenie, s. 136-137.

${ }^{44}$ Kgch, Relacje, sygn. 89, s. 287-291, Uniwersał JKM do szlachty ziemi chełmskiej, Warszawa 25 IV $1670 \mathrm{r}$.
} 
miał posłużyć królowi do sprawdzenia stanowiska szlachty względem zamiaru króla o zwołaniu pospolitego ruszenia ${ }^{45}$.

Na gruncie lokalnym uniwersały wydawali także urzędnicy czy powołani przez sejmik dowódcy. Przykładem takiego uniwersału jest ten, który wystosował 21 IX 1672 r. pułkownik pospolitego ruszenia ziemi chełmskiej Samuel Regowski, wzywający szlachtę do stawiennictwa pod swoją komendę. Taki rodzaj uniwersału był bardziej oszczędny w słowach od królewskiego i nie zawierał tak rozbudowanej narracyjnej warstwy propagandowej. Pułkownik napisał po prostu:

\section{(...) dosyć czyniąc funkcji mojej włożonej na się od WMM Panów i Braci do wiadomości donoszę, że (...) ruszam się zaraz spod Chełma (...) upra- szając WMM Panów i Braci żebyście się (...) przybywać do nas raczyli (...).}

Powołując się zatem na uprawnienia swojej funkcji, wezwał wprost szlachtę do stawiennictwa na pospolite ruszenie i wyprawę $\mathrm{w} 1672 \mathrm{r}^{46}$

Wspomniany Samuel Regowski był bohaterem również innego ważnego dokumentu, związanego z samorządowymi formacjami zbrojnymi. W sierpniu 1652 r. król Jan Kazimierz wystawił mu list przypowiedni na 100-konną chorągiew kozacką, którą uprzednio uchwalił sejmik chełmski 11 VI 1652 r. ${ }^{47}$ Monarcha potwierdził postanowienia sejmiku w zakresie wyznaczenia tego konkretnego rotmistrza, rodzaju formacji wojskowej oraz obiecanego żołdu ${ }^{48}$.W ten sposób chorągiew mogła funkcjonować w pełni legalnie. Listy przypowiednie bardzo często zawierały również informacje o momencie, od którego zaczynano naliczać służbę danej jednostce, o miejscu popisu czy uzbrojeniu żołnierzy. Czasami pojawiały się w nich nawet nazwiska komisarzy przeprowadzających lustrację chorągwi.

W przypadku dokumentów zaprezentowanych powyżej, mamy możliwość poznania dalszych losów danej formacji, a mianowicie tego, czy w ogóle mogła ona fizycznie zaistnieć czy stanowiła jedynie zapis w Księdze Grodzkiej. Dowiadujemy się zatem, czy dana formacja została zalegalizowana przez władze państwowe czy wyznaczono jej miejsca koncentracji, popisów etc. Uniwersały królewskie, które najczęściej poprzedzały decyzje sejmików, zawierały propozycje odnośnie do

${ }^{45}$ L. Wierzbicki, Pospolite ruszenie, s. 120.

${ }^{46}$ Kgch, Relacje, sygn. 91, s. 703-704, Uniwersał pułkownika Samuela Regowskiego do szlachty chełmskiej, Chełm 21 IX 1672 r.

${ }^{47}$ ASZCh, s. 322-323, Laudum sejmiku przedsejmowego 11 czerwca 1652 r.

${ }^{48}$ Kgch, Relacje, sygn. 74, s. 437-438, List przypowiedni JKM dla Samuela Regowskiego, Warszawa 20 VIII $1652 \mathrm{r}$. 
zaciągania formacji w danych okolicznościach. Najczęściej chodziło o wyprawy pospolitego ruszenia, na które należało wydać wici, ale poruszały one również kwestie innych formacji. W listach przypowiednich znajdowały się też dodatkowe specjalistyczne uwagi, np. o uzbrojeniu danej formacji wojskowej. Jest to pomocne przy uzupełnianiu informacji, jeśli takowych zabraknie np. w laudum.

\section{Zarządzenia/uniwersały funkcjonariuszy sejmiku}

Oblata pism w Księgach grodzkich dotyczyła również specjalnych dokumentów, związanych bardzo ściśle $\mathrm{z}$ daną formacją. Są to m.in. rejestry popisowe i akta komisji kombinacji łanów. Te pierwsze mogły być sporządzane dla wszystkich trzech formacji, ale największa ilość tego typu dokumentów dotyczy pospolitego ruszenia. $W$ takich spisach możemy odnaleźć wszystkie osoby z imienia i nazwiska, które danego dnia stawiły się na popisie ${ }^{49}$. Dla zobrazowania posłużmy się rejestrem z września 1672 r. Wymieniony został w nim dowódca, uczestnicy pospolitego ruszenia oraz przysłane poczty. Na popisie stawiło się 131 osób $^{50}$. Rejestry popisowe są bardzo pomocne nie tylko w badaniach nad stanem liczbowym formacji samorządowych, ale przydają się również w wielowymiarowych analizach społeczeństwa szlacheckiego. Są one również dowodem na faktyczną realizację decyzji odnośnie do formacji, uchwalonych na sejmiku.

W aktach będących wytworem komisji do kombinacji łanów mamy dane z przeprowadzonej lustracji pod kątem możliwości wystawienia żołnierzy z danej miary ziemi. Komisja kombinacyjna, która zebrała się 24 V 1653 r., przeliczała łany pod kątem wystawienia z nich piechoty pod komendą rotmistrza Jana Karola Romanowskiego. W aktach komisji wypisane zostały wszystkie miasta, miasteczka, wsie, starostwa, probostwa czy biskupstwa z wyliczonymi łanami bądź dymami i możliwościami werbunkowymi. Aby zobrazować rodzaj informacji, które zawarte są w aktach, posłużmy się cytatem:

Biskupstwo Chełmskie z miasteczkami i wsiami także władyctwo wsi

Parypse i wsi probostwa Uchańskiego mają pod wszystkich łanów sto

${ }^{49}$ R. Kozyrski, Popisy (okazowania), s. 346-347.

${ }^{50}$ Kgch, Relacje, sygn. 91, s. 776-779, Rejestr popisu pospolitego ruszenia szlachty chełmskiej, Lublin IX 1672 r.; H. Gmiterek, Rejestry szlachty, s. 335-339. 
trzydzieści pięć. Przychodziłoby się stawić pachołków trzech i pół pachołka lecz to do decyzji sejmowej i sejmiku relationis odkładamy.

Z przeliczenia łanowego udało się ostatecznie wystawić 100 żołnierzy ${ }^{51}$. Dokumentacja komisji kombinacyjnych dostarcza wielu kluczowych informacji o potencjalnej liczebności wypraw łanowych i zarazem pozwala dowiedzieć się o stopniu zaawansowania organizacji wypraw.

Dokumentacja specjalistyczna w podobny sposób, a być może nawet bardziej niż dokumenty władz centralnych i lokalnych pozwala na odtworzenie dalszego procesu organizowania formacji zbrojnych samorządu, ze szczególnym uwzględnieniem poziomu jego zaawansowania. Rejestry popisowe czy akta komisji kombinacyjnych są poświadczeniem tego, czy popisy w ogóle miały miejsce i czy odbywały się w wyznaczonym terminie, jak liczne były zaciągi i jak wyglądała w rzeczywistości realizacja zapisów uchwał. Niestety wszystkie przytoczone dokumenty dawały pewien wgląd w sytuację jedynie na pewnym, wczesnym etapie formowania samorządowych sił zbrojnych, natomiast próżno w nich szukać szczegółów dotyczących ich uczestnictwa w działaniach wojennych.

\section{Pozostałe dokumenty}

Takie informacje można znaleźć w pokwitowaniach, protestacjach, asygnacjach, atestacjach, manifestacjach czy pozwach przed sąd hetmański. Gdy żołnierze dokonywali pewnych czynności, obojętnie, czy były to czyny niedozwolone, wybieranie pieniędzy i zaopatrzenia, zwolnienia z uczestnictwa w obowiązkowych popisach czy poświadczenia pewnego stanu rzeczy, wszystkie były wpisywane do Ksiąg grodzkich po to, by nadać im charakter prawny. Pokwitowanie wystawione przez S. Regowskiego potwierdzało, że odebrał on pieniądze na swoją chorągiew powiatową, która została uchwalona przez sejmik ${ }^{52}$.

W manifestacji rotmistrz wojska powiatowego, o którym już wspomniano, S. Stawski oświadczał, że skompletował swoją chorągiew i wyruszył z nią do obozu wojskowego $0^{53}$. Żołnierze z jego chorągwi za służbę zostali docenieni i nagrodzeni

${ }^{51}$ Kgch, Relacje, sygn. 74, s. 1954-1958, Akta komisji kombinacji łanowej na wyprawę w 1653 r., Chełm 24 V 1653 r.; ASZCh, s. 345-346, Laudum w czasie popisu 10 czerwca 1653 r.; D. Kupisz, Wyprawy żotnierza, s. 110.

${ }^{52}$ Kgch, Relacje, Akta Luźne, sygn. 3, k. 242, Pokwitowanie Samuela Regowskiego.

${ }^{53}$ Kgch, Relacje, sygn. 90, s. 1771, Manifestacja Stanisława Stawskiego. 
na sejmiku 27 IV $1672 \mathrm{r}^{54} \mathrm{~W}$ Księdze grodzkiej z roku następnego chorągiew Stawskiego z kolejnego zaciągu została pozwana przed sąd hetmański, w wyniku którego nałożono na nią karę infamii. Według treści pozwu, żołnierze wzięli pieniądze przynależne $\mathrm{w}$ ramach żołdu, a następnie nie wykonali powierzonych sobie zadań i rozjechali się ${ }^{55}$. Przyczyną tego zajścia był toczący się wówczas spór polityczny pomiędzy królem a opozycją, $\mathrm{w}$ wyniku którego żołnierze nie zwalczali podjazdów tatarskich, a kłócili się między sobą. W ostateczności ci z chorągwi Stawskiego porzucili swojego rotmistrza i przeszli do obozu opozycyjnego. Oficerowi zarzucono zdefraudowanie 6000 złp i nakłanianie żołnierzy do dezercji ${ }^{56}$. Sprawa $\mathrm{z}$ rotmistrzem Stawskim znalazła się również w protestacji pułkownika pospolitego ruszenia Jana Karola Romanowskiego, także kierującego swoje zarzuty wobec rotmistrza oraz przeciwko innym, których oskarżył o zniesławienie ${ }^{57}$.

Treść przytoczonych dokumentów obrazuje jedno - chorągwie brały udział $\mathrm{w}$ działaniach zbrojnych oraz miały miejsce zdarzenia, które były z nimi związane. Dzięki atestacji wystawionej dla wojewodzica witebskiego Fryderyka Sapiehy z powodu jego nieobecności na popisie pospolitego ruszenia pod Hrubieszowem, które miało zostać użyte $\mathrm{w}$ wojnie $\mathrm{z}$ Turcją $\mathrm{w} 1621 \mathrm{r}$., możemy dowiedzieć się, że szlachta chełmska faktycznie odbyła popis i stawiła się konno do wyprawy ${ }^{58}$. Wartość dokumentu dodatkowo podkreśla fakt, że nie zachowało się z tego okresu żadne laudum ani rejestr popisowy.

Dzięki zaprezentowanym materiałom oraz innym tego typu utrwalonym w Księgach grodzkich wiemy, czy uchwalone jednostki wojskowe brały udział w kampaniach wojskowych, zostały zwinięte oraz jaki był ich dalszy los po sformowaniu i odbyciu popisu. Oczywiście nie dostarczają nam one pełnych informacji, ale uzupełniając je o wiadomości zawarte choćby w korespondencji, diariuszach czy innych materiałach źródłowych, możemy rzetelnie odtworzyć działalność samorządowych formacji zbrojnych w działaniach wojennych.

${ }^{54}$ D. Kupisz, Wojska powiatowe, s. 289; idem, Choragwie powiatowe, s. 67.

${ }^{55}$ Kgch, Relacje, sygn. 91, s. 727-730, Pozew kasztelana J. Piaseczyńskiego przeciw Stanisławowi Stawskiemu, Obóz pod Lublinem 27 X 1672 r.; ibidem, s. 782-79o, Dekret infamii przeciw żołnierzom chorągwi powiatowej Stanisława Stawskiego, 28 X 1672 r.; D. Kupisz, Wojska powiatowe, s. 130.

${ }^{56}$ D. Kupisz, Wojska powiatowe, s. 293; L. Wierzbicki, Szlachta chetmska, s. 64-65.

${ }^{57}$ Kgch, Relacje, sygn. 91, s. 714-718, Protestacja Jana Karola Romanowskiego, 7 XI 1672 r.

58 ASZCh, s. 138-139, Atestacja marszałka sejmiku dla Fryderyka Sapiehy wojewodzica witebskiego. 


\section{Podsumowanie}

Badając charakter, organizację, formę i działalność formacji zbrojnych samorządu szlacheckiego, niezbędne jest wykorzystanie materiałów zawartych w Księgach grodzkich, gdyż tylko dzięki nim jesteśmy w stanie w ogóle rozpocząć analizę tego zagadnienia. Dzięki treści Ksiąg możemy opisać cały proces tworzenia wojsk od samego początku, czyli uchwalenia na papierze danej formacji, przez jej popisy i formowanie składu, aż po rzeczywisty udział w walce. Istotny jest również fakt, że dokumentacja zawarta w Księgach grodzkich ma charakter urzędowy, dzięki czemu ryzyko przekłamania informacji w nich zawartych jest zdecydowanie mniejsze niż np. w prywatnej korespondencji. Oprócz tego zdecydowana większość dokumentów jest datowana, co pozwala nam jeszcze precyzyjniej odtworzyć przebieg wydarzeń. To wszystko sprawia, że chcąc podjąć się poważniejszej analizy zagadnienia, jakim są samorządowe formacje zbrojne okresu przedrozbiorowego, musimy skorzystać z materiału umieszczonego na kartach poszczególnych ksiąg. W ujęciu terytorialnym Księgi grodzkie chełmskie dostarczają na tyle kompletny materiał analityczny, że można było dzięki niemu odtworzyć obraz zarówno zaangażowania sejmiku szlacheckiego w poszczególne konflikty zbrojne prowadzone przez Rzeczpospolitą, jak i zapewniania bezpieczeństwa własnemu terytorium.

\section{Summary}

\section{Chelm Town Records as a Source for Studies on the Functioning of Armed Formations of Gentry Local Government}

The growing competences of Polish nobility sejmiks (dietines) during the Polish-Lithuanian Commonwealth caused gentry meetings to become one of the main political tools of the state. Local self-governments, through sejmiks, regulated many issues starting from financial ones to administration, personal, social, religious and to military matters. The latter were particularly important in the conflict-torn First Commonwealth (Republic of Poland). For many years the studies on this problem were not fully satisfactory. Notes on the subject appeared rather in the general-military or sejmik monographs. This trend, however, is slowly changing. To properly study the issue of the local government military forces it is necessary to use the rich source of Town Records (Report series) The included documents, especially the sejmik resolutions, allow us to reconstruct in detail the 
process of formation, organization, and participation of the armed forces raised by the local government in warfare. The author of the article, through analysis of the source material in Chełm municipal records, wants to show which documents included in the books are most helpful in reconstructing the whole procedure connected with the formation of local government military forces.

\section{Bibliografia}

\section{Źródła drukowane}

Akta sejmikowe Ziemi Chetmskiej 1572-1668, oprac. W. Bondyra, H. Gmiterek, J. Ternes, Lublin 2013.

Volumina Constitutionum, t. 3 (1611-1640), vol. 1 (1611-1626), red. S. Grodziski, M. Kwiecień, A. Karbowicz, Warszawa 2010.

Volumina Legum, t. 5, Od 1732 do 1782 roku, Petersburg 1860.

\section{Literatura}

Borowiak A., Wojska powiatowe przed kampania piławiecka w 1648 r., [w:] Staropolska sztuka wojenna, t. 2, red. Z. Hundert, Oświęcim 2013, s. 129-160.

Ciesielski T., Wyprawa łanowa 1653 r., „Zeszyty Naukowe Wyższej Szkoły Pedagogicznej im. Powstańców Śląskich w Opolu. Historia”, t. 30, 1994, s. 47-80.

Gmiterek H., Rejestry szlachty ziemi chetmskiej z lat 1669-1672, „Rocznik Chełmski”, t. 2, 1996, s. 327-339.

Gmiterek H., W czasach Rzeczypospolitej szlacheckiej, [w:] Chetm i chetmskie w dziejach, red. R. Szczygieł, Chełm 1996, s. 51-66.

Hahn K., Pospolite ruszenie wedle uchwat sejmikowych ruskich od XVI do XVIII wieku, „Pamiętnik Historyczno-Prawny”, t. 6, 1928, cz. 4, s. 5-87.

Hundert Z., Między buława a tronem. Wojsko koronne w walce stronnictwa malkontentów z ugrupowaniem dworskim w latach 1669-1673, Oświęcim 2019.

Kozyrski R., Popisy (okazowania) szlachty w Rzeczypospolitej w II połowie XVII w. Popis Chetmian $z 7$ sierpnia 1649 r., „Rocznik Chełmski”, t. 7, 2001, s. 341-358.

Kozyrski R., Sejmik szlachecki ziemi chetmskiej 1648-1717, Lublin 2006.

Kriegseisen W., Sejmiki Rzeczypospolitej Szlacheckiej w XVII i XVIII w., Warszawa 1991.

Kupisz D., Choragwie powiatowe ziemi chetmskiej w XVI-XVII wieku, „Rocznik Chełmski”, t. 10, 2006, s. 57-71.

Kupisz D., Wojska powiatowe samorządów Małopolski i Rusi Czerwonej w latach 1572-1717, Lublin 2008. 
Kupisz D., Wyprawy żołnierza łanowego w Koronie w czasach Jana Kazimierza, Warszawa 2018.

Łosowski J., Akta sądów i urzędów szlacheckich w XIV-XVIII wieku, [w:] Dyplomatyka staropolska, red. T. Jurek, Warszawa 2015, s. 447-458.

Łosowski J., Kancelaria grodzka chetmska od XV do XVIII wieku. Studium o urzędzie, dokumentacji, jej formach i roli w życiu społeczeństwa staropolskiego, Lublin 2004.

Łosowski J., Uniwersały królewskie i ich rola w procesie przygotowania działań wojennych na szczeblu powiatu w XVII w., „Studia Archiwalne”, t. 2, 2006, s. 73-94.

Nagielski M., Pospolite ruszenie szlachty w świetle kampanii zborowskiej i beresteckiej przeciwko Kozakom (1649-1651), [w:] Armia i społeczeństwo, Studia Historyczno-Wojskowe, t. 3, red. T. Ciesielski, Zabrze 2009, s. 94-112.

Prochaska A., Z dziejów samorządu ziemi chełmskiej, „Przegląd Historyczny”, t. 6, 1908, cz. 1, s. 33-49, cz. 2, s. 155-172, cz. 3, s. 306-321.

Staręgowski B., Działalność wojskowa i polityczna Jana Karola Romanowskiego - rotmistrza i podkomorzego ziemi chełmskiej, „Rocznik Chełmski”, t. 20, 2016, s. 45-58. Staręgowski B., Oficer wojsk formacji zbrojnych samorządu ziemskiego - na przykładzie Samuela z Pękosławia Regowskiego, podczaszego chełmskiego, „Rocznik Chełmski”, t. 21, 2017, s. 25-44.

Staręgowski B., Praktyczne znaczenie przekazu wojennego w uniwersałach króla Jana Kazimierza 1648-1668, [w:] Przekaz informacji o wojnie i na wojnie. Z dziejów wojskowości polskiej i powszechnej, t. 8, Homo Militans, red. A. Niewiński, Lublin 2019, s. 130-146.

Ternes J., Sejmik chełmski za Wazów (1587-1668), Lublin 2004.

Wierzbicki L., Pospolite ruszenie w Polsce w drugiej połowie XVII wieku. Ostatnie wyprawy z lat 1670-1672, Lublin 2011.

Wierzbicki L., Szlachta chełmska w czasie konfederacji gołębskiej, „Rocznik Chełmski”, t. 6, 2000, s. 55-70.

Wierzbicki L., Uczestnicy wypraw pospolitego ruszenia koronnego w czasach panowania Michała Korybuta Wiśniowieckiego, [w:] Społeczeństwo staropolskie, t. 4, Społeczeństwo a wojsko, red. I. Dacka-Górzyńska, A. Karpiński, M. Nagielski, s. 150-166.

Wierzbicki L., Wici na pospolite ruszenie w Koronie w latach 1669-1673, „Res Historica”, t. 26, 2008, s. 43-48.

Wimmer J., Wojsko polskie w drugiej połowie XVII wieku, wyd. 2, Oświęcim 2013.

Wimmer J., Wojskowość polska w latach 1648-1699, [w:] Zarys dziejów wojskowości polskiej do roku 1864, t. 2 (1648-1864), red. J. Sikorski, Warszawa 1966, s. 5-203.

Wyczański A., Z dziejów reform skarbowo-wojskowych za Zygmunta I. Próba relucji pospolitego ruszenia, „Przegląd Historyczny”, t. 43, 1952, z. 2, s. 287-304. 